\title{
Channel 4: Broadcasters Support Filmmakers
}

\author{
By Gerald Pratley \\ Fall 1996 Issue of KINEMA
}

\section{A DISCUSSION at the Vancouver Film Festival 1995}

Among the many discussions taking place during the Trade Forum at Vancouver's International Film Festival was a rapt and lively presentation of how Broadcasters Support Filmmakers. The principal speaker was David Aukin of Channel Four who was introduced by Wayne Skeene, President of Skeene Communications in Vancouver.

WS: David Aukin is a Commissioning Editor and Head of Drama for Channel 4, that "idiosyncratic little company" as Variety puts it, "that defies all the rules of Hollywood." The New York Times calls David "arguably the most influential figure in the British film industry." The Daily Telegraph calls him "The Sun King of the Silver Screen" and there's more: "The mastermind behind the largest filmmaking budget in Britain." David studied law at Oxford, worked for a period as a solicitor, made a career change to theatre in 1970 when he became literary adviser to the Traverse Theatre Club in Edinburgh, and before he joined Channel 4 in October 1990, David had been the Executive Director of the National Theatre for four years. As Commissioning Editor for Channel 4's Film on Four he has been responsible for more than 50 feature films, some partly, others fully financed by Channel 4. In May [1995] his budget was increased from o12 million to œ16 million, enabling him to produce 18 movies a year. To those of you who have been living in dark caves these past thirteen years, Channel 4 has not only transformed the British industry, but many feel that it has now set the world model for independent film production in the 21st century.

When it first went to air in 1982 critics referred to it as "Channel Snore" when describing its mix of weighty documentaries, arcane arts coverage and unrelenting educational programmes. Granada TV's Gus Macdonald called it "The unemployed making the unwatchable." Five years later with such titles as My Beautiful Laundrette, Paris Texas and Room With a View on the screen, the complaints gave way to praise for Channel 4's "gutsy, innovative programming" and its commitment to get involved in co-productions with independent producers. In effect, helping to fill the vacuum created by the lack of government funding for film producers. Under David Aukin's guidance, Channel 4's honour roll added such titles as Merchant-Ivory's Howard's End, Neil Jordan's The Crying Game and Richard Curtis's Four Weddings and a Funeral. A large part of Channel 4's mandate is to work with first-time filmmakers, a development direction that helped spawn titles such as Blue Juice, Bahji on the Beach and Danny Boyle's Shallow Grave, a first film that David Aukin backed heavily and one that has already made \$25 million (US) world-wide. David, welcome to Vancouver.

DA: I'm delighted to be here and thank you very much for inviting me. I feel very much at home in this very English room and it's a pleasure to be able to talk to you. Would you like me to start by talking about Channel 4 -- I am sure there are many who don't know how Channel 4 operates. Let me, if I may, give a potted history and for those who know it, my apologies. Channel 4 was established 12 years ago as an alternative to the mainstream ITV network -- Independent Television Network which is the commercial stream. The BBC already existed with its two channels BBC 1 and BBC 2, ITV was the third channel. It wanted its equivalent BBC 2 and they invented Channel 4, which did not belong to the ITV Network; but the ITV Networks in those days, when they started, took responsibility for selling all the advertising on Channel 4 and then each year they would give us a budget, based on the revenues that they had collected both for ITV and Channel 4. They put all the revenues together in one pot and gave us $14 \%$ of the total and that would always be our budget for the following year. We were established as a not-for-profit public broadcaster with a guaranteed budget, knowing each year in advance, what we had to spend.

That's how Channel 4 started, and we had to provide alternative programming to what was being shown on ITV. The other important thing to remember is that we were probably one of the very first publisher broadcasters and I never quite knew what that term meant. But what it means is this: Channel 4 itself doesn't produce anything, it doesn't produce the news, it doesn't produce the weather, it doesn't produce 
documentaries, it doesn't produce films, it doesn't produce anything. Everything is commissioned from independent production companies, so, the creation of Channel 4 spawned the independent production sector in the UK to an extent that had been previously unknown. This sector has now become bigger and bigger and indeed, other companies, including the BBC, now commission work from the independent production sector. But it was Channel 4's creation that created the demand and the need to have a large independent production force in the UK.

That is how Channel was set up and I think it's not very different today from what it was ten years ago in the sense that there are about sixteen chief commissioning editors of which I am one. Commissioning editors are responsible for their own areas, whether it be religion, drama, documentary, news, or whatever, and within their areas they are given a budget and told how many hours they have to produce for that budget, but beyond that, they are pretty well given autonomy to exercise their taste and judgement as to what programmes they want to commission. So they have enormous freedom and it means that decision making within the Channel is very simple. If the commissioning editor says No, there is no appeal, and if the commissioning editor says Yes, then it happens.

Obviously it's never nice to get a No, but if you do it comes pretty fast and you know that's final. There isn't a system of bureaucracy to go through where you get a maybe, or a maybe maybe, and it goes up a ladder until finally God decides yes or no. It is a very clear and simple decision making process I think the production sector appreciates, provided they get some approvals. Five years ago the Thatcher government decided this was all too much of a good thing and they tried to undermine what Channel 4 was going because it was clearly too successful. They decided that the Channel must sell its own advertising, cannot have a guaranteed budget from ITV, must separate itself from ITV, and must become a competitor to ITV, I think those concerned with this decision were certain the channel would flounder under that sort of competition.

So they negotiated a fail-safe clause which meant that if the channel didn't get enough advertising, if it went below a certain level, then ITV would still have to chip in with some extra money to boost our budgets. If we exceeded a certain percentage then we would have to pay ITV $50 \%$ of any excess commercial advertising that we received this is not profit, just commercial advertising revenue. No one seriously expected that Channel 4 would be paying any money to ITV.

Well, over the two years that this scheme has been operating, the channel has had to pay one hundred million pounds to ITV -- money that would otherwise have gone into the independent production sector to create new programmes for the channel. In other words, advertisers love Channel 4. It doesn't have a big audience, it has about a $14 \%$ share of the total, the network has about $22 \%$ of the commercial network in terms of audience figures, but the advertisers want their stuff on Channel 4 and it looks like this year we are going to make another surplus and pay ITV probably a cheque for sixty million pounds. And there is no sign that we are ever going to be able to call on any money for ITV to be paid to us in the reverse. Now, Channel 4 was never meant to be subsidizing ITV and it's ridiculous that we have to subsidize our strong major competitor whose audiences are usually twice, if not three times, our size. But that is the situation.

And, of course, as we said to our Tory government: This is ridiculous. You shouldn't be giving moneys to ITV shareholders, you should be giving it to Channel 4 to be able to invest in our programmes. We don't have shareholders, all our money, our profits, go straight back into programming. Well, to the Conservative government, if you ask them what would they prefer, money to shareholders or money to be spent on programmes, there's no competition -- it has to be money for shareholders. So we have completely lost that argument, and I think our only chance for change is to return a Labour government to power. This is how Channel 4 generally works and within that context of commissioning from the independent sector, of course films fitted in very easily. That was one of the few sectors where there was an independent production sector where film companies obviously existed and Channel 4, under my esteemed predecessor David Rose, who was there for the first six years of the channel, started commissioning wonderful films like My Beautiful Laundrette, Wish You Were Here, etc.

As with any new channel starting up, Channel 4 went through a teething period. I wasn't working there at that time, but I loved it as a viewer. What happened was it was the channel where the breaks would always be smudged; occasionally they would have to fill in for a few minutes, it wasn't really very professional. Personally, I found it terribly refreshing -- everything now is so streamlined with every second of screen time 
being filled with promotions or commercials. It was very much relaxed and a bit amateur then but we've become very professional in the last few years! And, of course, that has been reflected in higher ratings and everything comes in on that. It just took time for the channel to find its feet, but it produced some wonderful programmes in those early years, and it would be foolish to take that quote, "Channel Snore," too literally.

Your commissioning process for independent films seems, compared to the Canadian experience, to be so simple.

Yes, that's right and although many companies now have copied the channel in terms of being publishers, they do this now for economic reasons as it is much cheaper to have a publishing broadcaster than to be a production broadcaster and I think it's a sad day that the BBC is decreasing the amount of resources it puts into production. It is essentially a production house as I suspect the Canadian Broadcasting Corporation is essentially a production house; as an organization, as an institution it feels comfortable as a production house and feels very uncomfortable working as a commissioning house. Channel 4 is completely the reverse -- we only understand the commissioning process, I know nothing about the production side and that's not what I'm employed for. Institutionally we are absolutely there to work hand-in-glove with the independent sector.

However, to the independent trying to get a commission or a licence, it sounds like Channel 4's experience is simpler, more direct, more Yes and No, much easier to take as opposed to the laborious, bureaucratic way of moving though the CBC and other funding agencies. You have said previously, "What I commission is a reflection of my own personal taste and judgment. It would be difficult having to defer to committees." I think that's a luxury in Canada we, the independents, would love to have.

Well, I think it's a luxury that we only enjoy in Britain, I think, at Channel 4. Most organizations are more centralized, there's no question. Decisions always tend to go up and up and I think one of the strengths of the channel has been that it's had two heads -- first Jeremy Isaacs and currently Michael Gray -- who are arguably the two best broadcasters of their generation in the UK, and both fiercely protective of the channel and who understand totally the concept of delegation and believe in it. I think the channel's own particular personality and idiosyncrasy comes from allowing these sixteen commissioning editors to exercise taste and judgment and not trying to second-guess them or over-rule them. And when they go wrong they defend us, they may or may not renew our contracts, and if things go right they take all the glory.

We probably get something like four to five thousand submissions a year. We commission 18 films a year. At any given time we probably have something like 60 projects in development, and there are three of us who are responsible for this area, plus half-a-dozen very able overworked readers. So clearly within this context I read what my colleagues tell me I should read, and the scripts work their way up. I love reading but a lot of what I read is of course scripts that are in development and going through new drafts, scripts that are in production and going through the amendments. When I come out here I've got scripts all the time to read, but these are mainly scripts we are all working on. This is one of the problems with this job really, you can spend $90 \%$ of your time working on stuff you are not going to make into movies and only $10 \%$ on the stuff that is going to become a movie. You've got to be very careful to make sure that as much of your concentration as possible goes into the things that are actually going to happen.

But there are two other important elements to consider when talking about institutionalisation, and how this works for the channel. You see, one of the major reasons why more television companies won't finance movies in their own countries -- and actually I believe that indigenous filmmaking is wholly reliant on local television companies financing local filmmakers, if they don't no-one else will -- is that the money is just not going to be there. Another reason why so many are reluctant to do this is because of scheduling. No-one is interested in the long term today, everyone is only thinking about tomorrow, literally tomorrow. So what television companies do, when they put money aside for a drama, whether a film drama or a TV drama, is that they want to see it on the screen as quickly as possible, they want their money translated on screen fast. Channel 4 doesn't work this way. It has made an investment, which probably costs it something like $œ 30$ million a year, whereby the films we commission don't get shown on the channel for over two years. We allow those films first to go into cinemas, we exploit them theatrically, then go on video, and then finally they get their British premiere on Channel 4 two years later. 
Now this is a huge financial investment by the channel which we've trained the channel into making so the accountants, the finances, accept it because it's just part of the balance sheet, they understand it. For a company to start that process today, especially when most of them are under huge pressure either, as the CBC because their budgets are under threat or with commercial companies because they are maximizing profits, the idea of making that sort of investment doesn't look terribly attractive. And I think this is just short-termism. In fact, the glory of film on 4 is that not only do we work with the film sector that allows us to get co-finance with other film companies around the world, but more importantly, we are building up a catalogue of films for the channel which is invaluable, and will work for the channel down the line, so that the moneys we are investing are going to produce films for showing not just once, but six, seven, eight times on the channel and each time bring in huge returns for us. It's a major investment; the returns are not today but three years down the line.

That's the kind of investment that you seriously have to make as a TV company if you're going to get involved in financing feature films. The sort of films we are making don't star Arnold Schwarzenegger or Sylvester Stallone and they don't therefore have massive marketing budgets behind them, the only thing that sells them is their quality. To get that quality known, talked about and understood and to make people want to see those films, the theatrical release becomes the marketing tool for the television company. The prime example is The Crying Game, a film that, if we had shown it immediately on TV, would have got a tiny audience. No-one knew then who Stephen Rae was, no-one was then that interested in Neil Jordan, the subject matter was very difficult for a British audience.

The success of the film theatrically in the UK and in America meant that when we did show it on Channel 4 it was one of the biggest "pullers" of the season -- the film was known about. It means we can take risks with films in terms of content, subject matter, lack of stars, unknown directors, we can make those sort of risks and gambles because we know that if the films work theatrically then they are going to do well when they are shown on television. So the theatrical release actually increases, I believe, the overall a potential TV audience.

Because of the commercial success of so many of your films of late, have you been accused of "going commercial" and abandoning minority programming? You're in it just to make money?!

I think one of the problems we faced in the UK was that few audiences were going to see British movies. We would have wonderful successes abroad with films by Ken Loach and Mike Leigh but in Britain not many moviegoers would go and see these films when they were shown in the cinemas. There was a feeling within the film community, and certainly something I was very conscious of, that we had to re-establish a pact with our audience. We needed films to be seen by huge numbers in cinemas and for people to enjoy that experience in order to re-establish the sense that you could go to the movie house, see a British movie and not be disappointed that it wasn't an American movie.

The trick is not to make films that achieve this by just copying the Americans, no, the trick was to do that without compromising the sort of movie you wanted to make, but at the same time, to be very conscious that you were making it for a British audience. And I'm very proud of the fact that we succeeded in doing this in a number of films with the result that we made money. But from my point of view, because I don't share in this money, what was important was that these films were being seen by the British public. In that respect probably the most significant film we commissioned in all this period was Shallow Grave, which was shown first in the UK and recovered its production costs within the UK. That is the basis of a healthy film industry. When you can make a film in your own country and recoup it within your own country, then the rest of the world is the icing on the cake. And that's how we should be making films because we can't compete with the Hollywood big budget productions. We want to go on making our own films for our own audiences, and of course sometimes the more specific and the more particular they are to our own society the more universal they become and the more they will mean to people abroad.

It's astonishing, but I never thought Four Weddings and a Funeral would work anywhere else outside the UK, it was the biggest shock to me -- I don't know what people see in it -- I mean, it's so British I can't understand it! So we are always being taken by surprise, but we knew our audience, we thought our audience was the UK, we were doing it for the British public. It was a film for us, and it became a film for the world, 
and that's very exciting but it doesn't happen all the time, it happens very rarely, but if it can work for your own audience and you can recoup your costs within your own territory, then you've got the basis of a film industry.

No-one wanted to put a penny into Four Weddings. It was rejected by everyone before it came to me. It was a very exciting period -- I was just a young man in those days, and Richard Curtis was a young, impoverished writer then. He came to me and said: I have an idea for a play, would you commission it? He was broke, so I gave him, I don't know, a thousand pounds or something, because I knew he was hugely talented and he knew that he wouldn't be able to write a stage play and I knew he wouldn't really be able to write a stage play, and he knew that $I$ knew he wouldn't be able to write a stage play, but I didn't think it mattered because I knew that somewhere in some form Richard would some day produce something wonderful, and in the meantime it is important to keep writers like him going.

And I always feel that the payoff to that came to be Four Weddings and a Funeral many years later, and yes, we worked a lot on it and it's a very personal film. Richard Curtis got engaged to Emma Freud on the day that we green lighted the film and they still haven't married -- he can't make that commitment! It's a very personal movie! I think that all our movies, finally, are very personal, they are not formulaic movies and you know that's why I am very proud of that film and it fits perfectly within the concept of Film on 4.

How much of an influence is your background in theatre when making your script decisions? When I started I was so self-conscious about my theatrical background that I very consciously refused to consider anything that had a theatrical provenance -- I went the other way. Now I will take good material from wherever it comes. I guess I'm confident enough now having been in the job five years that I'm not going to be inhibited by any preconceived ideas. I was trying to say to everyone -- the filmmakers -- that I'm not interested in literary adaptations, I'm not interested in the old style British heritage movie, I want to encourage contemporary British films, original stories, and make a distinguishing mark for the channel in terms of what it was commissioning. And, having done that, you can then start to spin off and break all your rules.

Incidently, there are no British content requirements, but clearly my priority is British films. That means probably that something like $80 \%$ of my budget is spent on British films and British filmmakers but there is always a $20 \%$ part of the budget which is available for non-British films. It's not to do with the content, it's to do with the audience really, it is very difficult to make a film for people who are 6,000 miles away, especially with first-time filmmakers. The whole development process is one where you hope to make the script better but you get to know the filmmakers and you trust them, or not. It's a very important part of the process and I can't really do that with filmmakers who are not in the UK but I do occasionally, as with Tod Haines and Alison Anders, two American filmmakers I have been helping in the past Hal Hartley is another one.

The scenario of Shallow Grave came in by a first-time scriptwriter called John Hodge. He had never written a script before in his life. A first-time film director Danny Boyle and a first-time producer Andrew Macdonald. Many people thought it was a huge risk, but it was a sensible budget at $œ 1.1$ million. And it was a wonderful script -- we did some work on it of course -- but from the first time I read it just jumped off the page and what I mean by that is that John Hodge as a writer had a style and a signature which is all too rare when you read screenplays today. He not only understood the medium but he had a rhythm for his dialogue, characters just came to life before you.

In terms of trying to define where we stood, I certainly was encouraging people not to be frightened of genre films. I don't say it has to be, but don't be frightened by the thriller or whatever. When people say: What are you looking for, it's a question that's always put to me, of course, at such sessions as we are having today, the answer is: Don't ask me what I'm looking for, what I'm looking for is what enthuses you. In the end, I work off your passions and your talents. If you look at the slate we are supporting, you see a wide range of films and filmmakers, people who have nothing in common with each other. You can't categorize. I defy anyone to categorize my choices in terms of a particular type of film. I'm just looking for quality and talent -- this is the shorthand, we're backing talent not concepts. If people say, Wouldn't it be a great idea to make a film about whatever, I say why? 
It depends who's making it and why that makes it interesting, that's what distinguishes it, if you like, from the TV movie where you say, We must do a film about O.J. [Simpson]. Hundreds of executives around Hollywood are today planning their films, or have been for the last decade. It doesn't interest me, but I guess if Altman came along and said, Wouldn't it be great to do a film about...well, yes, that might be interesting, but it depends who and why they want to do it, what their line is. Primarily, we work through the production companies but there is nothing to stop anyone approaching me and, indeed, everyone does -writers and directors -- and on several occasions writers have said, This is an idea, and I like the idea and they say, I prefer just to develop the first draft with you and see what we have before we go to a production company. And that's fine, we will do that. Production companies get upset, they think I'm doing too much of that. But it's my right and there's nothing constitutionally to stop me.

The power of the commissioning editor is absolute but the important thing is not that commissioning editor should ever make decisions which he or she doesn't believe in, because of who they are, but rather that there should be a multiplicity of places to go to with your ideas, so if I do say No, there are other doors to knock on to try to get funding for your idea. The problem in the UK has been that there are so few doors to go to in order to get backing for ideas, so that if I do say No and the BBC say No, then there are very few other places to turn to. That's what is wrong.

Question from Mr. MacEwan: It's interesting to hear from Jim Burt that the CBC is willing to take on yet another onerous responsibility -- that of saving Canadian theatrical film at a time when Canadian television needs to be concerned about saving itself. We live in a situation here with Canadian television almost totally enslaved to American television which is utterly inward-looking. The major Canadian production companies have announced that they are interested in developing projects which are primarily now for the American market before they can consider their suitability for the Canadian market.

Yesterday at a session, a director of Telefilm said that they are now backing off from its Canadian content requirement in the hopes of recouping some more money. Many of us in this country are working in television because of the impossibility of finding an audience through Canadian theatrical film, and that the hope of recouping on a film in Canada is just so distant that we only have television for finding an audience. But now we are in a situation when even a national public broadcaster is telling us that ideas and stories are too Canadian for it to consider them. I am wondering Mr. Aukin when you were getting started, if you had had to face that restriction, if you had had to face that hurdle that stories were too British to proceed, would you have ever been able to accomplish what you had done?

No, absolutely not. It seems to me that the whole basis of the strategy we are following is on the fact that we can't compete with Hollywood, shouldn't try to compete with America, and should make films that they wouldn't make, couldn't make, and don't want to make. But when we make them sometimes they look at them and say, that's wonderful. But we are making something so different that it creates its own place in the market. To try to take on the Americans head-on is, to me, a strategy doomed to failure commercially, let alone artistically and culturally. Interestingly the most successful work in terms of UK television, the most successful dramas, TV dramas as well as films, generally week in week out are the ones about British stories with British actors.

Coronation Street, East Enders have the biggest viewings, and in terms of our films it's true as well. British films -- a film like Hope and Glory, the John Boorman film, gets enormous audience figures every time you show it, because it's about our own country and our own heritage, and the audiences respond to that. Recently we have formed our own company to distribute our films in the UK There is a problem in the UK on the distribution side which is why we formed our own company to do it. This is a new development and it is too early to say whether it's going to be successful or not, but there is a shortage of good distributors.

There used to be a paranoia that however good the film was you wouldn't get a real shot to get at the British audiences because the British circuits were again dominated by the American film companies. The one British one, Rank, had absolutely no interest in British films that I can discern whatsoever. So for many years everyone was blaming them, but in fact, filmmakers had to take some responsibility and when we do produce films that British audiences want to see, we have no problem in finding cinemas and screens to show 
them. I think the first responsibility has to remain with the filmmakers to make the films that they want to make, but in such a way that audiences want to see them as well.

Question from the floor: The point I want to make is not so much a criticism but a distinction between Film Four and the Canadian broadcast scene in that, it seems to me that you support artists and stories on the merit of their visions and are prepared to take risks in a way I can't imagine happening here under our situation. I can't imagine CBC backing movies like Naked, or Shallow Grave, or The Crying Game, or even My Beautiful Laundrette. I would say that deciding things by committee as we do and being aware of political correctness ends up being the enemy of risky, exciting, dramatic story telling.

Channel 4's public profile is to be edgy, to be pushing boundaries, to be innovative, to absolutely take risks; this is part of our brief, of our public image and of the reason why people watch us. It is built into the purpose of the channel that we should be different.

Question from the floor: In terms of getting that first crucial contact on the ladder, perhaps David could give us a brief rundown of what Channel 4's short film programme Short-andCurlies is all about.

Short-and-Curlies, which we have been running for many years in collaboration with British Screen, is actually coming to an end and we are starting a new strand with the BBC called Brief Encounters. Essentially the point is the same -- it is arguably the most important strand of what we do. We are going to commission on Brief Encounters eight shorts, they have to be precisely 11 minutes in length, they will be made on 35mm, with union agreements in place, no favours, and the budget is GBP 80,000 , or $\$ 170,000$ Canadian? Which is quite generous, we think, for an 11-minute film, but as a result of that strand we have found the filmmakers with whom we want to work and commission a full length feature.

There's a list of about half-a-dozen filmmakers who came out of this programme. There are a number who learned not to make full length feature films, but that's the point of the exercise, it works both ways. But it does give opportunities to would-be filmmakers who have never before made a full length feature, and that's the only criterion, a chance to make an eleven-minute feature film. Our relationship with British Screen is in decline, that's the polite way of putting it. You don't want to know why! It is of course due to Rupert Murdoch -- he turns up everywhere and has probably turned up here in some form or other.

British Screen did a deal with Murdoch under which he would get the first screenings of all our films. Come on! Films on 4 is one of the defining strands of Channel 4, so that fell apart. Fortunately it hasn't made a pennyworth of difference because it has coincided with a situation where we are finding partners who want to work with us all over the world, and that's very gratifying, long may it continue. And it is an alternative source of income, otherwise you either go to British Screen or you go to the BBC, but you can't go to a combination of them. I think that's all we need in the end, a multiplicity of many companies to go to.

Question from the floor: Your financial support to new filmmakers -- could you give a summary of what you pay for scripts?

Sure. I think the minimum we pay is GBP 14,000 for a first draft and once the cameras roll, it's usually GBP 60,000. By the way, we have a major new source of funding in the UK, the single most successful lottery in the whole world, the British are absolutely obsessed by it. I never buy a ticket but I'm a winner, they are financing our movies -- it's astonishing!

(Transcribed by Patricia Thompson)

\section{Author Information}

Gerald PRATLEY, OC, LLD, started his career as film critic with the CBC. In 1969, he founded the Ontario Film Institute which he directed until 1990. He has written several books and numerous articles on film, including Torn Sprockets, a history of Canadian cinema. He taught Film History in universities in Toronto and Waterloo, Canada and holds three honorary degrees from Canadian and US universities.

Gerald A. Pratley (1923-2011) was born and educated in London, England, and came to Canada in 1946. 
He started working in Toronto for the $\mathrm{CBC}$ as a scriptwriter. He was drawn toward working in motion pictures, and became, in 1948, the CBC's first film critic and commentator.

Gerald Pratley broadcast three programmes a week, Pratley at the Movies, The Movie Scene, Music From the Films, and others, until 1975. During this time he also became the first post-war chairman of the Toronto Film Society, chairman of the Toronto and District Film Council and co-founder of the A-G-E Film Society and correspondent for international magazines such as Films and Filming, Film In Review, Variety, Hollywood Quarterly and International Film Guide. During the 1950s he wrote for Canadian Film Weekly and Canadian Film Digest.

He became known as a speaker on all aspects of motion picture art and industry, and was invited to teach film history at the University of Toronto, York University, University of Waterloo, Seneca College and Ryerson Polytechnical University, with individual lectures being given at many other Canadian and US universities and colleges. He has served as a member of various judging panels of competitions and festivals, being one of the members of the first Canadian Film Awards in 1949.

From 1970 to 1975 he was the director of the Stratford (Ontario) International Film Festival, and from 1969 to 1976 he was Chairman of the International Jury of the Canadian Film Awards. He has attended all the world's leading festivals of film, and in particular, for 30 years, the Cannes Festival as CBC correspondent. He has written six books, The Films of Frankenheimer: Forty Years in Film; The Cinema of John Frankenheimer; The Cinema of Otto Preminger; The Cinema of David Lean; The Cinema of John Huston, and Torn Sprockets, a history of the Canadian cinema.

Gerald Pratley has served on the Advisory Boards of the film departments of Ryerson Polytechnical University and Humber College, and as a member of the programme committee of TV Ontario. In 1968 he became the founder-director of the Ontario Film Institute of the Province of Ontario, an organization which has distinguished itself in archival holdings and public service and is known since 1990 as the Cinematheque of Ontario. He taught Film History courses at the Department of Film and Photography, Ryerson Polytechnic University, Toronto and the University of Waterloo.

In 1984, Gerald Pratley was made a Member of the Order of Canada and in 2003 Officer of the Order of Canada for his service to Canada through film appreciation. He holds Honorary Degrees in Letters and Fine Arts from York and Waterloo Universities (Ont., Canada) and Bowling Green State University (Ohio, USA).

In 2002, Gerald Pratley received a Special Genie Award from the Academy of Canadian Cinema \& Television in recognition of his lifelong dedication to the promotion and his exceptional support of Canadian cinema.

He died on 14 March 2011 in Ontario, Canada. 